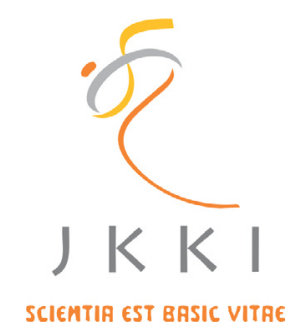

Jurnal Kedokteran dan Kesehatan Indonesia

Indonesian Journal of Medicine and Health

Journal homepage : www.journal.uii.ac.id/index.php/JKKI

\title{
Pulmonary metastasis of recurrent giant-cell tumor in proximal humerus: a case report
}

Aris Kurniawan ${ }^{1}$, Mujaddid Idulhaq $^{1}$, Pamudji Utomo ${ }^{1}$, Ambar Mudigdo $^{2}$, Handry Tri Handojo ${ }^{3}$

${ }^{1}$ Department of Orthopaedic \& Traumatology, Faculty of Medicine, University of Sebelas Maret, Dr. Moewardi General Hospital, Prof. Dr. R. Soeharso Orthopaedic Hospital, Surakarta, Indonesia

${ }^{2}$ Department of Pathology, Faculty of Medicine, University of Sebelas Maret, Surakarta, Indonesia

${ }^{3}$ Department of Radiology, Prof. Dr. R. Soeharso Orthopaedic Hospital, Surakarta, Indonesia

Case Report

\begin{tabular}{|c|c|}
\hline & \\
\hline ARTICLE INFO & \multirow{5}{*}{$\begin{array}{l}\text { Giant-cell tumour (GCT) of the bone is a benign neoplasm which commonly } \\
\text { occurs in the distal femur, proximal tibia, and distal radius. The proximal } \\
\text { humerus is a relatively rare site of occurrence, with a prevalence rate of } \\
4 \% \text {. We report a case of a } 40 \text { years-old male with a recurrent GCT of the } \\
\text { proximal humerus. Wide excision and hemiarthroplasty of the shoulder } \\
\text { was performed. However, the tumour recurred. Asymptomatic metastasis } \\
\text { to the right lower lobe of the lung was found on plain radiograph. We } \\
\text { suggest that multiple surgeries would increase the risk of local recurrence } \\
\text { of GCT that will lead to pulmonary metastasis. }\end{array}$} \\
\hline & \\
\hline & \\
\hline & \\
\hline$\overline{\text { DOI : } 10.20885 / J K K I . V o l 10 . I s s 2 . a r t 12}$ & \\
\hline & \multirow{2}{*}{$\begin{array}{l}\text { Giant-cell tumor (GCT) adalah tumor pada tulang yang umumnya jinak } \\
\text { dan terjadi pada femur bagian distal, tibia proksimal, dan tulang radius } \\
\text { distal. Kejadian pada tulang femur bagain proksimal relatif jarang dengan } \\
\text { prevalensi hanya 4\%. Laporan kasus ini terjadi pada seorang laki-laki } \\
\text { berumur } 40 \text { tahun dengan GCT pada humerus proksimal yang mengalami } \\
\text { rekurensi. Eksisi luas dan hemiartroplasi bahu telah dilakukan, namun } \\
\text { tumor mengalami rekurensi. Metastasis asimptomatik ke lobus kanan } \\
\text { bawah paru ditemukan pada foto polos. Kami menduga bahwa beberapa } \\
\text { operasi akan meningkatkan risiko kekambuhan GCT lokal yang akan } \\
\text { menyebabkan metastasis paru. }\end{array}$} \\
\hline $\begin{array}{l}\text { Copyright @2019 Authors. } \\
\text { This is an open access article } \\
\text { distributed under the terms } \\
\text { of the Creative Commons At- } \\
\text { tribution-NonCommercial } 4.0 \\
\text { International Licence (http:// } \\
\text { creativecommons.org/licences/ } \\
\text { by-nc/4.0/). }\end{array}$ & \\
\hline
\end{tabular}

\section{INTRODUCTION}

Giant cell tumour (GCT) of bone, a benign but locally aggressive, has a prevalence of $5 \%$ of all primary tumours. ${ }^{1}$ The usual location of GCT is in the distal femur, proximal tibia, and distal radius. Another area is on the proximal humerus, but it is rare (prevalence rate is about $4 \%)^{2}$

Intralesional curettage is still the preferred method to maintain function even though it has a high risk of recurrence ( $12.5 \%$ to $45 \%$ ). Wide resection offers a theoretical advantage of lower recurrence risk by removing the entire tumour but with a chance of compromising functional outcome, particularly at the proximal humerus. Distant metastasis can be occurred in many sites, with decreasing frequency, at lung, liver, and skin. ${ }^{3}$

We presented a case of a patient with a benign recurrent giant-cell tumour of left proximal humerus who had an asymptomatic pulmonary metastasis after multiple operative procedures. Informed consent has been taken from the patient for this publication.

\section{Case report}

A 40 years old, smoker, the male was 
referred to our orthopaedic outpatient clinic due to an increasing mass on his left shoulder. He has occasional (intermittent) pain on his left shoulder while working or at rest. Visual Analog Scale (VAS) was graded at 5 to 6 . He has no motor weakness of his upper extremity. There was no history of trauma, fever or pain elsewhere of his body, and he claimed he was otherwise healthy. Past medical history, he claimed that he underwent some tumour resection and fixation in some local district hospital three years ago.
Physical examination revealed a deep-seated round mass, measuring $25 \times 20 \times 10 \mathrm{~cm}$, located at his proximal left shoulder. It was hard in consistency, non-mobile and attached to the underlying structure. The colour of the skin was the same as the surrounding, no redness or warmth of the skin. He could achieve the only flexion of 30 degrees, extension 10 degrees, abduction 45 degrees while adduction was full. His range of motion was limited by pain (Figure 1).

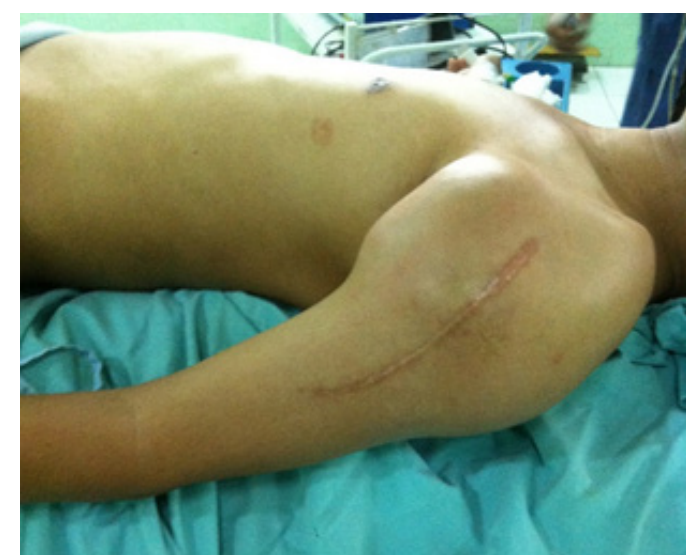

Figure 1. A round mass was located on the left shoulder with a size $25 \times 20 \times 10 \mathrm{~cm}$, showing hard consistency and non-mobile feature

Plain radiographs revealed bulging radiolucent mass with some sclerotic rim at medial side, extending from middle to proximal shaft of the left humerus. The rush nail was well fixated from proximal to distal of the humerus. There was no sign of plate and screw breakage (Figure 2).

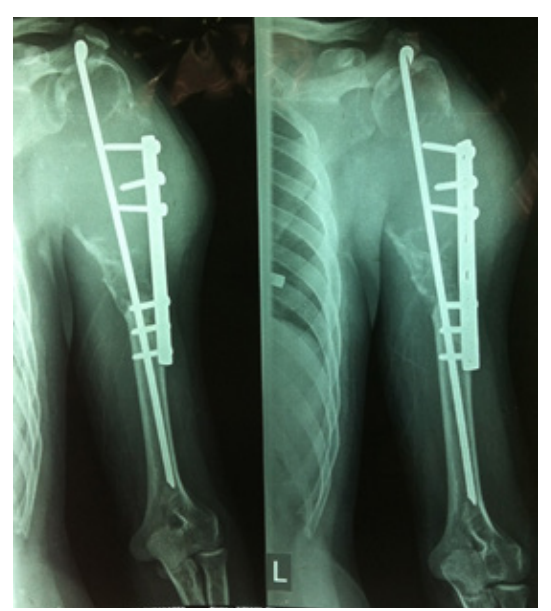

Figure 2. A soft tissue mass in the left shoulder having predominantly radiolucent density with some sclerotic rim on the medial side; The rush nail was well fixated from proximal to distal of the humerus. 
CT angiography was ordered to evaluate primary vascular status, feeding artery, and the nature of the lesion. The axillary and brachial artery showed good perfusion to the distal part of the limb. The tumour was graded as Campanacci grade 3 (Figure 3).

The patient was then admitted for wide resection. The shoulder was approached through the site of the previous incision with elliptical skin incision. Some of the deltoid muscle was taken with the mass but the biceps brachii and brachialis muscles are preserved. A shoulder hemiarthroplasty using Austin Moore prosthesis with $37 \mathrm{~mm}$ head diameter then performed (Figure 4). The postoperative biopsy result was Giant cell tumour with no sign of malignancy.

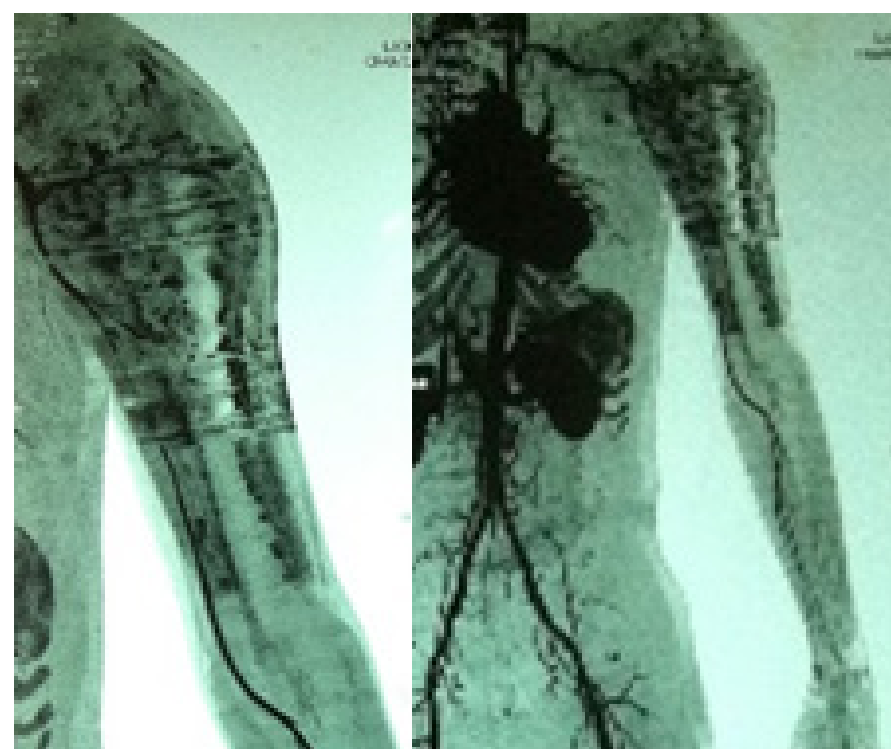

Figure 3. The main feeding artery from the axillary artery to the mass; The main artery showed good perfusion to the distal of the upper limb.

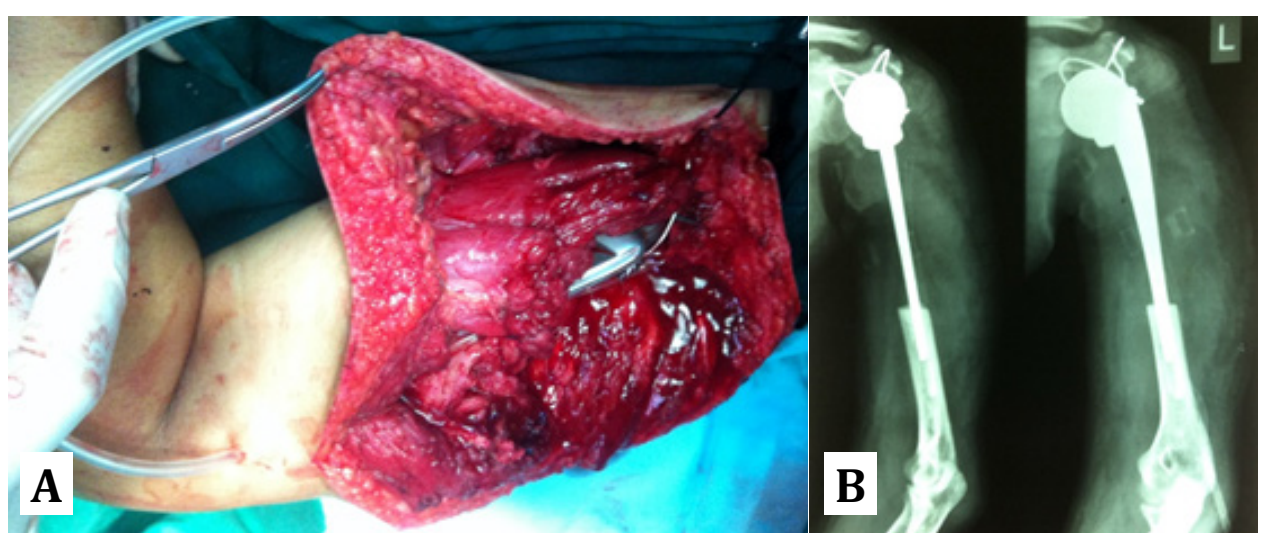

Figure 4. A) Wide resection of the recurrent GCT. B) Shoulder hemiarthroplasty using Austin Moore Prostheses

However, patient developed surgical site infection six months after surgery. He had debridement and removal of the implant performed in our hospital. A culture result of Staphylococcus Aureus was found, and specific antibiotic treatment was given for two weeks.

Four months after subsequent surgery, the patient presented a new recurrent mass at his left shoulder. The previous history before the mass was not significant. The clinical finding 
showed that there was a hypertrophic scar on the lateral side of the humerus, and an irregular round mass of hard consistency and nonmobile, measuring $15 \times 10 \times 7 \mathrm{~cm}$. At that time, MRI was performed, and the $\mathrm{T} 1$ weighted image showed low intensity (Figure 5).
While T2 weighted image showed heterogenous mixed high and low signal intensity in the lesion, further workup of recurrent GCT was carried out, and the patient was admitted for wide excisional biopsy (Figure 6).

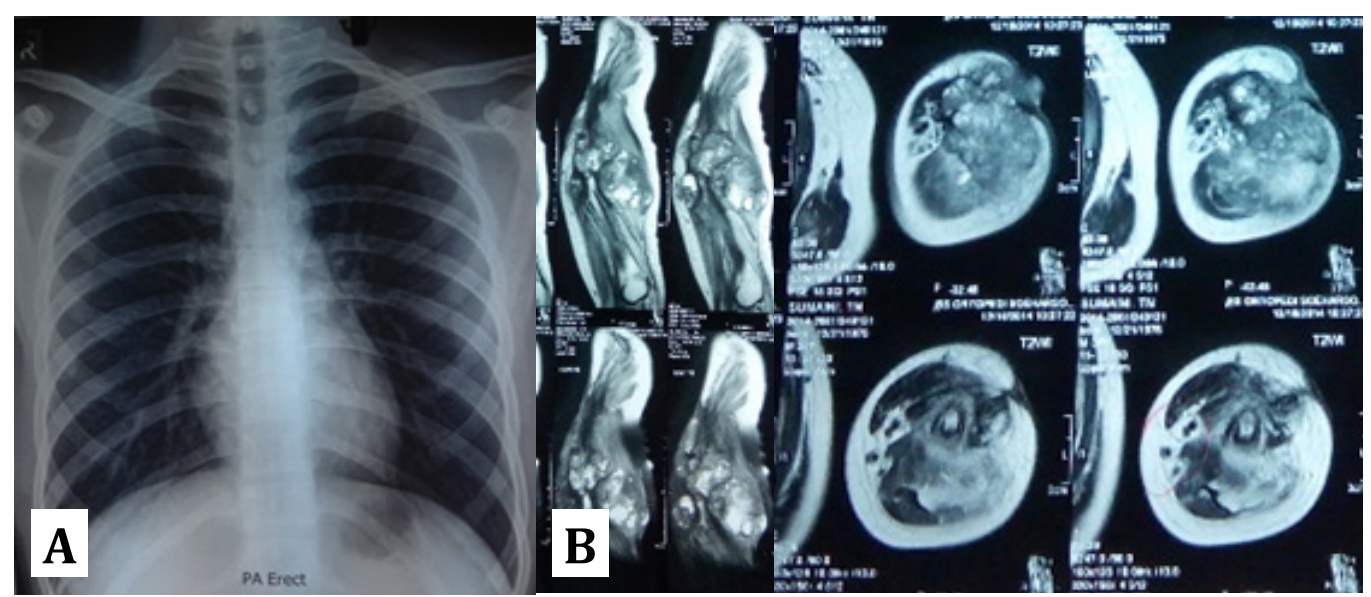

Figure 5. A) Chest $\mathrm{x}$-ray: no sign of metastasis. B) A soft tissue mass in the anterior compartment of the muscle of the left humerus with low intensity on T1 weighted image; T2 weighted image shows heterogeneous high signal with areas of low signal intensity.

Three months after the last wide excisional biopsy, the patient came to our outpatient clinic with a chief complain of growing mass on his left humerus. Clinical presentation at the time revealed an outgrowth mass of tumour extending from the proximal to the distal part of the humerus. There is multiple areas of ulceration with some necrotic patches but no pus discharge. He could hardly move his left shoulder due to pain. The plain radiograph showed massive growth of the tumor with a mixed area of lucency and ectopic calcification. We also took the chest $x$-ray and it showed a coin lesion at inferior lung field of right hemithorax. He was diagnosed with recurrent GCT with lung metastasis (Figure 7). Further management was shoulder disarticulation. Left lung metastasis will be observed strictly since it was asymptomatic at that time.

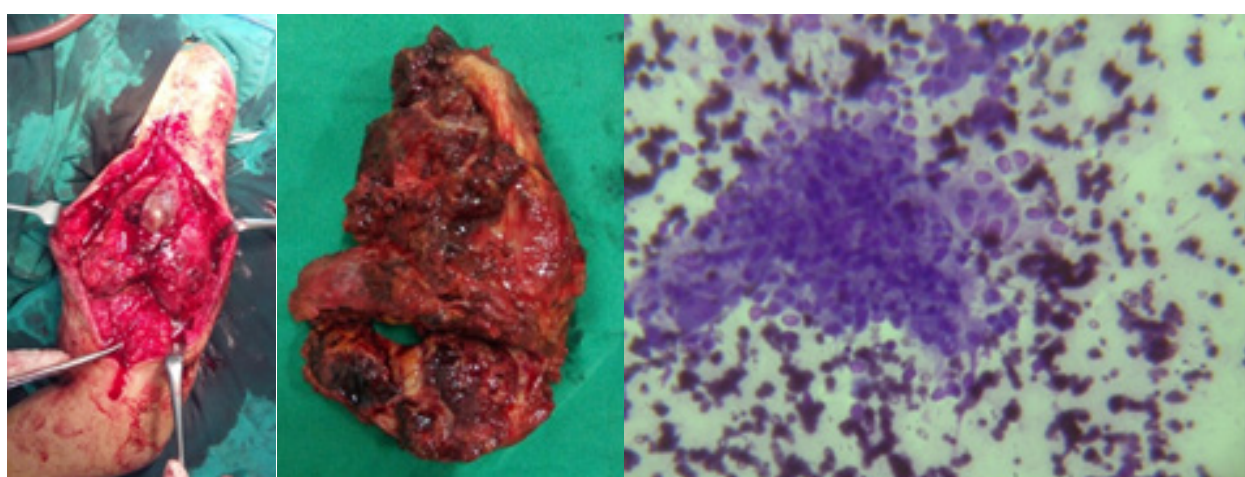

Figure 6. Wide excision and biopsy of the mass, it showed typical polymorphic cells with Giant-cell type osteoclast. 


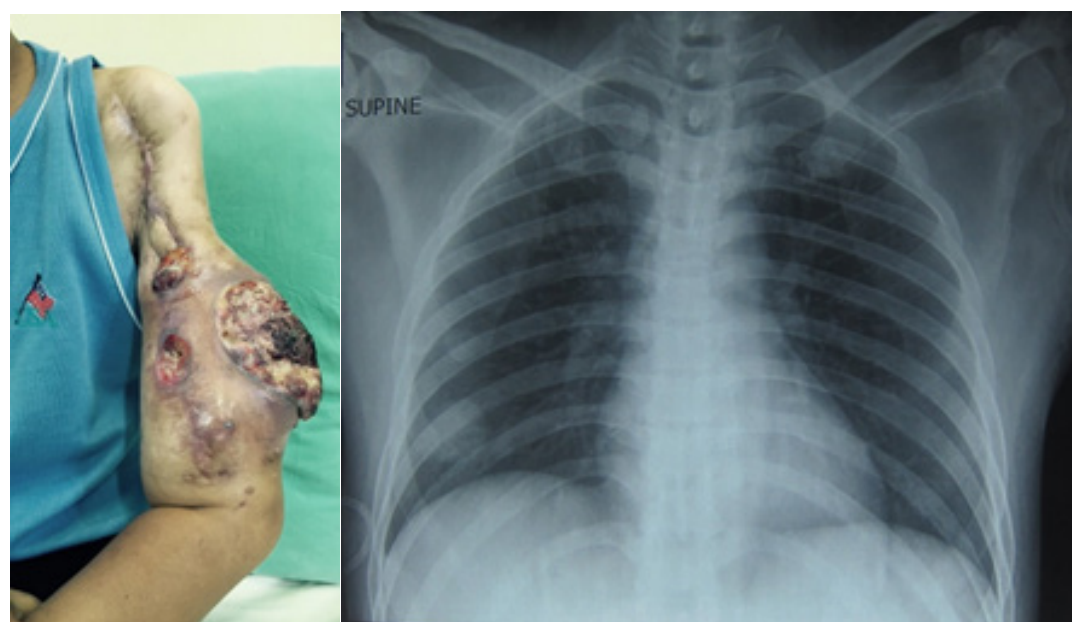

Figure 7. An outburst mass from the left humerus with some necrotic area but with no pus; Chest x-ray showed a coin lesion at the bottom of right hemithorax.

\section{DISCUSSION}

Giant cell tumour is a benign, locally aggressive, neoplasm with ability to recur and metastasize. The usual site for GCT is around the knee and away from the elbow. The proximal humerus is a rare site for GCT. ${ }^{4}$

$\mathrm{Xu}$ and colleagues demonstrated that age, gender, tumour location, pathologic fracture, and types of surgery were not risk factors for recurrence. Soft tissue involvement and GCT grade 3 and up are risk factors for recurrence in GCT. ${ }^{5,6}$ Local recurrence is one of the significant factors to induce pulmonary metastasis. ${ }^{7}$ Giant cell tumour patients who have more than two tumour recurrences showed a risk of pulmonary metastasis equal to or even higher than that of patients with malignant GCT of the bone. Other authors proposed that surgical manipulation could facilitate tumour migration, thereby promoting lung metastasis. The mechanism of metastasizing in this benign lesion was considered the same as a malignant lesion. The suggested mechanism is local vascular permeation and emboli formation that can be induced by multiple surgical manipulations. ${ }^{8}$ Thus, the above facts concurred with our finding why the patient was more vulnerable to pulmonary metastasis after several operations and tumour recurrence. ${ }^{9}$
The patient had to undergo multiple operations because of the demand from the patient to keep his arm for social-economic reason. The used of hip Austin Moore Prostheses implant instead of the shoulder implant has been carried out because the government is only cover for the hip implant.

In summary, preventing local recurrence of GCT for minimizing pulmonary metastasis could be done by avoiding multiple surgeries. We hope this report may have some value in understanding pulmonary metastasis of the GCT.

\section{CONFLICT OF INTEREST}

The authors have none to declare.

\section{Acknowledgement}

The authors have none to declare.

\section{REFERENCES}

1. Turcotte RE, Wunder JS, Isler MH, Bell RS, Schachar N, Masri BA, et al. Giant cell tumor of long bone: A Canadian sarcoma group study. Clinical Orthopaedics and Related Research. 2002;April(397):248-58.

2. Lackman RD, Crawford EA, King JJ, Ogilvie CM. Conservative treatment of campanacci grade III proximal humerus giant cell tumors. Clinical Orthopaedics and Related 
Research. 2009;467(5):1355-9.

3. Getty PJ, Peabody TD. Complications and functional outcomes of reconstruction with an osteoarticular allograft after intra-articular resection of the proximal aspect of the humerus. Journal of Bone and Joint Surgery. 1999;81(8):1138-46.

4. Rekha YB, Rao P. Recurrent giant cell tumour in distal humerus: A case report. Journal of Orthopaedic Case Reports. 2013;3(3):42-4.

5. Xu H, Niu X. Analysis of the risk factors for local recurrence of giant cell tumor of long bone. Chinese Journal of Oncology. 2014;36(6):465-8.

6. Noort-Suijdendorp AP, Kroep JR, Gelderblom H, Hogendoorn PCW, Taminiau AHM, Dijkstra PDS. Risk factors for local recurrence in giant cell tumour (GCT) of the long bone. Orthopaedic procedings. 2018;102(1):S161-175.

7. Chan CM, Adler Z, Reith JD, Gibbs CP Jr. Risk factors for pulmonary metastases from giant cell tumor of bone. Journal of Bone and Joint Surgery. 2015;97(5):420-8.

8. Nair GG, Supriya NK, Sathi PP. Benign giant cell tumor of bone with pulmonary metastasis- report of two cases and review of literature. International Journal of Research in Medical Sciences. 2017;5(3):1131.

9. Wang B, Chen W, Xie X, Tu J, Huang G, Zou C, et al. Development and validation of a prognostic index to predict pulmonary metastasis of giant cell tumor of bone. Oncotarget. 2017;8(64):108054-63. 